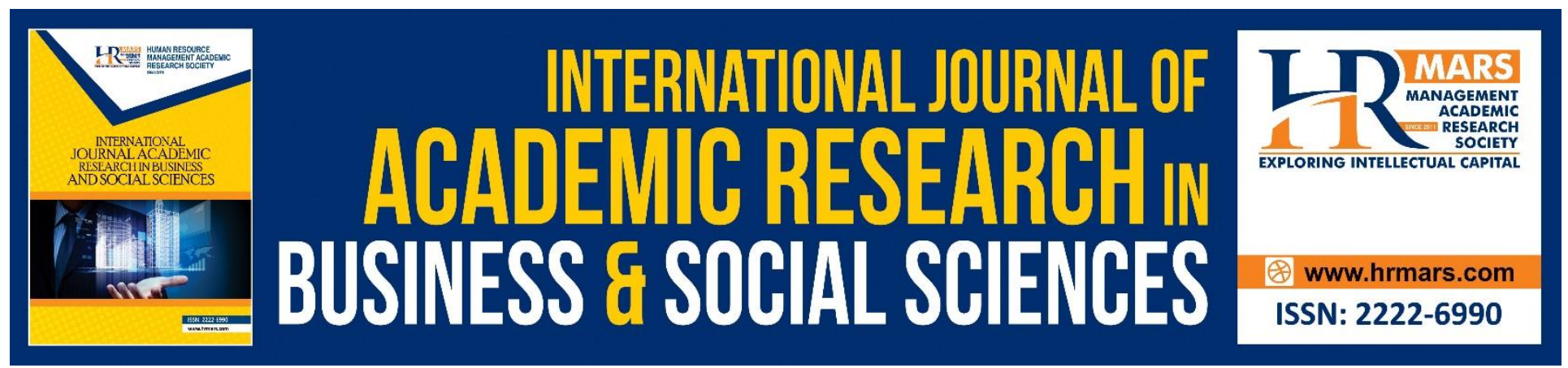

\title{
Halal Food Facilities in Japan from The Perspective of Malaysian Muslim Tourists
}

Wan Muhammad Wan Sulong, Salina Husain, Muhd Zulkifli Ismail, Mohd Sukki Othman, Zaid Mohd Zin, Rabihah Mohd Ghazali

To Link this Article: http://dx.doi.org/10.6007/IJARBSS/v10-i11/7949

DOI:10.6007/IJARBSS/v10-i11/7949

Received: 03 September 2020, Revised: 27 September 2020, Accepted: 20 October 2020

Published Online: 13 November 2020

In-Text Citation: (Sulong, et al., 2020)

To Cite this Article: Sulong, W. M. W., Husain, S., Ismail, M. Z., Othman, M. S., Zin, Z. M., Ghazali, R. M. (2020). Halal Food Facilities in Japan from The Perspective of Malaysian Muslim Tourists. International Journal of Academic Research in Business and Social Sciences. 10(11), 180-192.

Copyright: (c) 2020 The Author(s)

Published by Human Resource Management Academic Research Society (www.hrmars.com)

This article is published under the Creative Commons Attribution (CC BY 4.0) license. Anyone may reproduce, distribute, translate and create derivative works of this article (for both commercial and non-commercial purposes), subject to full attribution to the original publication and authors. The full terms of this license may be seen

at: http://creativecommons.org/licences/by/4.0/legalcode

Vol. 10, No. 11, 2020, Pg. 180 - 192

http://hrmars.com/index.php/pages/detail/IJARBSS

JOURNAL HOMEPAGE

Full Terms \& Conditions of access and use can be found at http://hrmars.com/index.php/pages/detail/publication-ethics 


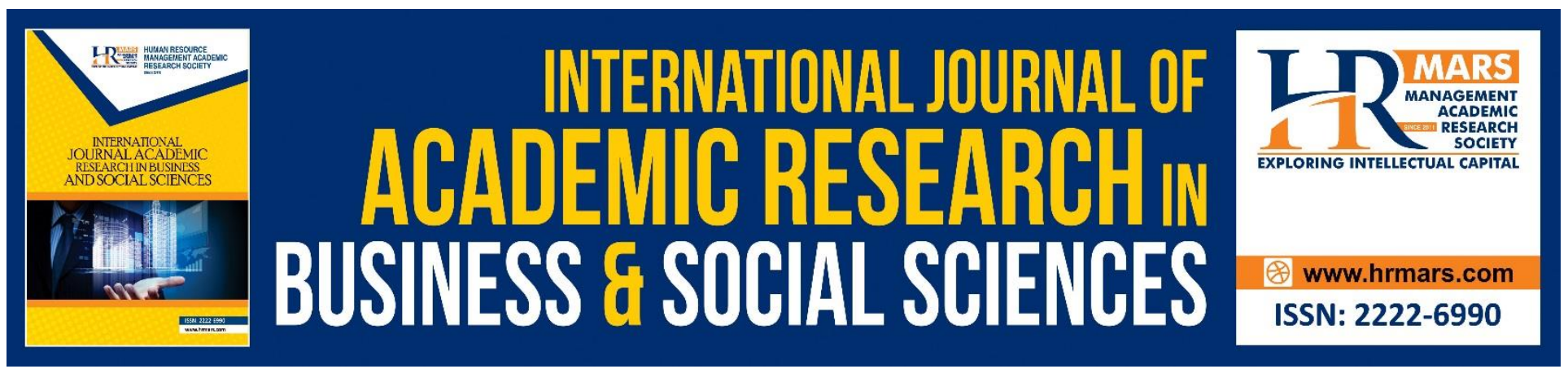

\title{
Halal Food Facilities in Japan from The Perspective of Malaysian Muslim Tourists
}

\author{
Wan Muhammad Wan Sulong ${ }^{1}$, Salina Husain², Muhd Zulkifli Ismail ${ }^{3}$, \\ Mohd Sukki Othman ${ }^{4}$, Zaid Mohd Zinn ${ }^{5}$ Rabihah Mohd Ghazali6 \\ 1,2,3,4,5 Faculty of Modern Languages and Communication, Universiti Putra Malaysia \\ ${ }^{6}$ Teacher Education Institute, Islamic Studies Campus, Selangor, Malaysia \\ Email:w_mhd@upm.edu.my, linahusain@upm.edu.my, zulismail@upm.edu.my, \\ msukki@upm.edu.my, zaidmz@upm.edu.my, ipgm-1191@moe-dl.edu.my
}

\begin{abstract}
In addition to being a popular destination for tourists worldwide, Japan is getting high marks for its efforts to become a halal-friendly tourist destination. Halal or Islamic tourism is a market segment that is fast growing not only in Muslim countries but globally due to the rapid growth of the Muslim population. Japan is at the top of the list of countries that increase their hospitality to Muslim customers. The purpose of this study is to investigate the perspective of Malaysian Muslims tourists towards halal food facilities based on their experience of a visit to Japan. Surveys via the questionnaire are the method used for data collection. The outcome of the study shows that respondents are very concerned about the halal status of food due to their understanding of the concept of halal food. Therefore, most of them only choose food that is believed to be permitted especially those with halal logo. Halal food is relatively easy to get at the airport and major tourist attractions. The presence of Muslim workers in halal premises adds to their confidence in the halal food provided. In terms of cost, respondents are less satisfied because the cost of halal food is relatively expensive.
\end{abstract}

Keywords: Halal Food, Halal Tourism, Muslim-Friendly Tourism, Halal Market, Japan

\section{Introduction}

The Muslim travel market continues to expand rapidly and to develop in a changing world. As one of the world's most expensive tourism markets, destinations, companies and travel-related organizations need to proactively build strategies to engage and attract this segment to their goals. The Muslim travel market is on track to continue its fast-paced growth to hit US\$220 billion by 2020 . A further US\$80 billion is expected to rise to US\$ 300 billion by 2026. Globally, an estimated 131 million Muslim tourists arrived in 2017, up from 121 million in 2016, and is expected to rise to 156 million visitors by 2020 representing $10 \%$ of the travel market (CrescentRating, 2018). 
INTERNATIONAL JOURNAL OF ACADEMIC RESEARCH IN BUSINESS AND SOCIAL SCIENCES Vol. 10, No. 11, 2020, E-ISSN: 2222-6990 @ 2020 HRMARS

Japan has long been a preferred destination for global travellers due to its unique culture, beautiful scenery and spectacular urban landscapes. The growth in the number of Muslim tourists to Japan has increased the availability of Halal food. In Japan, however, the participation of Japanese companies in this sector is still meagre compared to other global players, even though they face a growing obstacle in their domestic market. The Halal industry now holds the key to a broader international market, making it inevitable for Japanese food companies to see it as a strategic lever for repositioning efforts to enter this new market. This paper explores the perspective of Malaysia Muslim tourists towards halal food market in Japan, the unique characteristics of Japanese firms concerning the halal industry, the imperatives of Halal food industry in Japan and the perception of Japanese consumers towards Halal food.

\section{Halal Tourism}

talal refers to as lawful or permitted by Islamic law (Consumers Association of Penang, 2006). Most of the time, when it comes to Halal, it always positioned in mind as something related to food. Nevertheless, Halal covers broad areas of consideration such as purchase intention, source of income, attitude toward advertisement, attitude toward the product, word of mouth and religiosity. The coining of the term "halal tourism" reflects the rise of a travel market directed at Islamic devotees. The new awareness includes informing travellers about halal restaurants and offering pork-free food prepared in a manner approved by religious authorities. The devout travellers are also notified about prayer rooms in airports and shopping malls offering appropriate products (Tan, 2015).

Halal tourism that observes the precepts of Islam is becoming popular all over the world, especially among Muslim consumers (Mohsin, Ramli, \& Alkhulayfi, 2016). Muslims are encouraged to travel to see the beauty of the creation of Allah in nature and then to reflect on the goodness of the bountiful blessings of Allah upon humanity. Every location has its uniqueness and numerous attractions. Beautiful ranges of mountains, rivers, and lakes were not only bestowed, but also ethnicity, culture, and customs (Hasanah \& Harun, 2020).

As Muslim customers around the world assert their particular needs, the effect of halal is beginning to be illustrated by the tourism industry and hospitality services. Religiosity which refers to one's belief in God and commitment to act by the rules set forth by God (McDaniel \& Burnett, 1990), is also proven to have a significant influence on Muslim consumer decision making about the consumption of halal tourism (Eid \& El-Gohary, 2015; Shakona et al., 2015). Shazlinda Md Yusof \& Noriyuki Shutto (2014) mention that it is possible to classify Muslim travellers into three segments; those who want fully halal-friendly facilities for their travel; those who, if available, would use halal-friendly facilities; and those who do not care about halal-friendly activities. The breakdown is 3:5:2 for these three parts, so $80 \%$ of the USD 100 billion has a very high potential for halal-friendly tourism.

\section{Halal Food Market in Japan}

In Japan, there is scant literature about the Muslim population because, in this region, religion is not used as identification. Censuses and surveys often usually do not contain a religion issue. Since the Japanese national census does not include foreigners (which account for the majority of Japan's Muslim population), the exact number is difficult to ascertain (Kojima, 2006). In 2010, 190,000 
INTERNATIONAL JOURNAL OF ACADEMIC RESEARCH IN BUSINESS AND SOCIAL SCIENCES Vol. 10, No. 11, 2020, E-ISSN: 2222-6990 @ 2020 HRMARS

Muslims were estimated to live in Japan, an increase of 58 per cent compared to Japan's 120,000 in 1990 (Brian et al., 2011). Nonetheless, the scale is still tiny, representing about 0.15 per cent compared to the total Japanese population. Most of these Muslims are refugees, with Indonesians numbering about 30,000, followed by Pakistanis, Bangladeshis and Iranians as the largest group. There are very few, not more than 7,000 Japanese native converts, and most of them are Japanese women who have married foreign Muslim men (El-Maghrabi, Soliman, \& Adli, 1995).

Halal foods are permissible foods by Islamic rules, and Muslims are required only to consume them. Until recently, the idea of halal food has been unheard of in non-Muslim countries. The previously distinct aspect of Muslims is now becoming an international issue with the rise in understanding among them. Because of its vast target market of US\$ 661.6 billion as of 2010 (Agriculture and AgriFood Canada, 2011), halal food has become an attractive industry for businesses.

In Japan, however, the participation of Japanese companies in this sector is still meagre compared to other global players, considering the rising challenge they face in their domestic market. The Halal industry now holds the key to a broader international market, making it inevitable for Japanese food companies to see it as a strategic lever for repositioning efforts to enter this new market.

\section{Malaysia Muslim Tourists in Japan}

The majority of the Muslim population comes from some of the fastest-growing economies such as Indonesia, Malaysia, Turkey and the Gulf countries. Muslims are now becoming an important target market in the world. They will become an increasingly significant segment of business in all industries. Japan is one of the countries in Asia that is working hard to draw visitors from Muslim countries, including Malaysia.

To Muslim nations tourists, Japan is rolling out a red tap, with the qiblah (arrows pointing to Mecca ) in hotel rooms, and prayer rooms being signposted in airports and commercial complexes. That said, in addition to Halal food becoming a staple in restaurants and the cafeterias of companies that conduct business with firms from Muslim countries. The number of Muslims choosing to settle in Japan has steadily increased. Halal meals were first available on menus about a decade ago, but the recent tourism boom in the nation is driving supply and demand (Evan, 2017).

The total number of tourist arrivals in Japan in 2016 exceeded 24 million, well ahead of the 20 million targets set by the national government for 2020. And visitors from Muslim nations accounted for a rising number of arrivals. According to the Japan National Tourism Organization (JNTO), almost 271,000 Indonesians travelled to Japan in 2016, up from just 63,000 in 2009 . In the same way, more than 394,000 Malaysians arrived in 2017, up from 89,000 seven years earlier. The dramatic rise in arrivals from Southeast Asia is partly due to the Japanese government's easing visa requirements, the growth of low-cost airlines serving Japan, and the increasing middle class with higher disposable income, according to JNTO. Another contributing factor was the ease with which Muslim travellers would meet their unique needs. As pointed by Benner (2015) a combination of halal-friendly products and services and omotenashi (traditional Japanese hospitality), is beginning to emerge, offering exciting culinary and other options to a new wave of visitors to Japan. 
Japan has long been a destination of choice for global travellers due to its unique culture, beautiful scenery and spectacular urban landscapes. Travelling to Japan used to be very expensive, but the introduction of low-cost airline flights to Japan has boosted the tourism industry. Reasonably priced fares have prompted more Malaysians to consider Japan their destination for a tour (Tan, 2015).

The growth in the number of Muslim tourists to Japan has increased the availability of Halal food. This simple amenity is a significant problem for Muslim tourists in Japan due to the language barrier. The ingredients displayed on the food product label are written in Japanese, making it difficult for tourists to judge whether or not the product is consumable unless they are Japanese-speaking. They will use the food they carry home and lack the pleasure of trying local delicacies or saving money on buying local food. Otherwise, they'd have to rely on Japanese speaking guides or friends who can help with translations. Travelling in the month of Ramadan will create another problem since hotels do not have early meals instead of breakfast. Other basic amenities necessary for Muslim travel include a family-friendly travel setting, prayer and ablution facilities, religious travel services, and separate men-women swimming pools.

The emerging Halal industry in Japan initiated the establishment of a non-profit organization, the Japan Halal Association (JHA), which oversees the Halal certification of food outlets and goods, in addition to lobbying for places of prayer. JHA is a qualified and recognized member of the International Halal Alliance (IHI) and a licenced member of JAKIM. JHA uses JAKIM Malaysia's standard to help food producers or outlets receive halal certification in Japan. Also, JHA conducts training and certification for Halal managers in Japanese companies (Japan Halal Association, 2012). As a result, some Japanese tour companies have also been encouraged to introduce halal tour packages for Muslim tourists based in Tokyo and Osaka.

The availability of halal food in Japan would also promote the expansion of tourism initiatives, such as homestay programmes and exchange programmes. As Muslim tourists become more familiar with the availability of halal food and other necessities, the domestic halal market is expected to grow faster as revealed by a study conducted by Muhammad Khalilur Rahman (2014) that Islamic attributes and quality of service have a significant relationship to Muslim tourists' satisfaction and destination loyalty. On the same track, Mohamed Battour and Mohd Nazari Ismail (2014), in their study, attempted to test the relationship between tourism motivations and tourist satisfaction and to test how religion moderates the relationship. The results indicated that tourism motivations are significantly and positively related to tourist satisfaction. The results also showed that religion substantially mediates the relationship between pull motivation and tourist satisfaction.

\section{Objective}

This research aims to investigate views of Malaysia Muslim tourists in Japan toward halal food facilities during their visits and stay in Japan particularly aspects related to their concern with halal food, availability of halal food and level of confidence in consuming halal food.

\section{Methodology}

To accomplish the research, we generated 16 items from three independent variable (availability of halal food, confidence feeling towards halal food and religiosity in consuming halal food) and dependent variable tourist satisfaction. We used a pilot study with 30 respondents from the different 
INTERNATIONAL JOURNAL OF ACADEMIC RESEARCH IN BUSINESS AND SOCIAL SCIENCES Vol. 10, No. 11, 2020, E-ISSN: 2222-6990 @ 2020 HRMARS

demographic background who has ever visited Japan. Using Cronbach coefficient alpha, the value obtained for the instrument used in this study is 0.799 , indicating reliability and consistency. During pilot testing, some improvements were made in the questionnaire. After modifying the questionnaire, we distributed more than 300 questionnaires between May to September 2017. This research employs a survey via a convenient sampling procedure. Respondents were informed about the purpose of the study before distributing the questionnaire. Each of the named items was measured using a five-point rating scale (1=strongly disagree; $2=$ disagree; $3=$ neutral; $4=$ =agree; and 5= strongly agree). After examining the questionnaires, this research kept only those questionnaires that were fully completed by the respondents. For the successful completion of this research, this study has rejected 24 questionnaires and kept 288 questionnaires for analysis.

\section{Result and Discussion}

\section{Section A: Demographic Information}

In analyzing the data, Statistical Package for the Social Sciences (SPSS) 25 version software was used. Fulfilling the objectives of the present study requires assessing the characteristics of the participants in obtaining a foundation towards interpreting the outcomes of the analysis by understanding relevant aspects of the respondents. The age factor among the participants was a significant demographic aspect derived from the participants. The investigation revealed respondents aged between 18 and 30 years constituted a larger percentage of the sample denoted at $66.3 \%$, while those aged between 51 and 60 consisted of 3.5 per cent.

The race of the participants was also noted since Islam is a religion and not a tribe. For this reason, Malaysian Muslims could comprise of people from various ethnic backgrounds. For instance, table 1 illustrates that the Malay was 95.5 per cent, whilst Chinese Muslims accounted for only 2.8 per cent of the participants. A significant number of the participants estimated at $59.4 \%$ visited Japan for travel/leisure purposes, while 28.1 per cent of the respondents were there for studying reasons (see table 1). A large percentage of the participants (81.3\%) visited Japan between 2013 and 2017, with most of them staying less than one month (83.3\%).

The participants also identified Tokyo as the most visited place during their visit to Japan, evidenced by 49 per cent of the respondents selecting the city. Osaka, Kyoto and Kobe received the second most votes from the respondents (22.6\%) followed by Fukuoka and Nagasaki (13.5\%). According to the participants, Hotels were the most common type of accommodation available to them during their visit. Regarding their proficiency in Japanese, 71.9 per cent of the respondents claim no fluency in the language. 
INTERNATIONAL JOURNAL OF ACADEMIC RESEARCH IN BUSINESS AND SOCIAL SCIENCES Vol. 10, No. 11, 2020, E-ISSN: 2222-6990 @ 2020 HRMARS

Table 1: Respondent Demographics Data

\begin{tabular}{|c|c|c|c|}
\hline No. & Demographic variable & $\mathbf{n}$ & $\%$ \\
\hline \multirow[t]{5}{*}{1} & Age & & \\
\hline & $18-30$ & 191 & 66.3 \\
\hline & $31-40$ & 45 & 15.6 \\
\hline & $41-50$ & 42 & 14.6 \\
\hline & $51-60$ & 10 & 3.5 \\
\hline \multirow[t]{4}{*}{2} & Race & & \\
\hline & Malay & 275 & 95.5 \\
\hline & Chinese & 8 & 2.8 \\
\hline & Others & 5 & 1.7 \\
\hline \multirow[t]{5}{*}{3} & Purpose of visiting Japan & & \\
\hline & Travelling & 171 & 59.4 \\
\hline & Business & 7 & 2.4 \\
\hline & Studying & 81 & 28.1 \\
\hline & Others & 29 & 10.1 \\
\hline \multirow[t]{4}{*}{4} & Year and duration of stay in Japan & & \\
\hline & 2006 and before & 4 & 1.4 \\
\hline & $2007-2012$ & 50 & 17.4 \\
\hline & $2013-2017$ & 234 & 81.3 \\
\hline \multirow[t]{3}{*}{5} & Duration & & \\
\hline & Less than 1 month & 240 & 83.3 \\
\hline & 7 - 12 month & 48 & 16.7 \\
\hline \multirow[t]{6}{*}{6} & Place(s) visited & & \\
\hline & Tokyo & 141 & 49.0 \\
\hline & Osaka / Kyoto / Kobe & 65 & 22.6 \\
\hline & Hiroshima & 4 & 1.4 \\
\hline & Fukouka / Nagasaki & 39 & 13.5 \\
\hline & Others & 39 & 13.5 \\
\hline \multirow[t]{6}{*}{7} & Type of accommodation & & \\
\hline & Hotel & 129 & 44.8 \\
\hline & Hostel & 45 & 15.6 \\
\hline & Homestay & 40 & 13.9 \\
\hline & Capsule & 4 & 1.4 \\
\hline & Others & 70 & 24.3 \\
\hline \multirow[t]{3}{*}{8} & Proficiency in the Japanese language & & \\
\hline & Yes & 81 & 28.1 \\
\hline & No & 207 & 71.9 \\
\hline
\end{tabular}

\section{Descriptive Analysis}

The means and standard deviation of the responses were used to describe the datasets used for all the four aspects (see table 2). Halal food scored the highest mean (3.65), which is slightly above average according to the Likert Scale. The prayer facilities received the second-highest mean score 
INTERNATIONAL JOURNAL OF ACADEMIC RESEARCH IN BUSINESS AND SOCIAL SCIENCES Vol. 10, No. 11, 2020, E-ISSN: 2222-6990 @ 2020 HRMARS

(3.47) followed by ease of communication (3.42). Accommodation scored the least (2.69) showing that the respondents did not appreciate it during their visit to Japan. These findings are reliable since the standard deviation values for all the components were below one. Therefore, illustrating most of the value responses are less spread above and below the mean making their analysis reliable.

Table 2: Descriptive Analysis

\begin{tabular}{lll}
\hline Variables & Mean & SD \\
\hline Halal Food & 3.65 & 0.51 \\
Prayer Facilities & 3.47 & 0.61 \\
Accommodation & 2.69 & 0.76 \\
Ease Of Communication & 3.42 & 0.68 \\
\hline
\end{tabular}

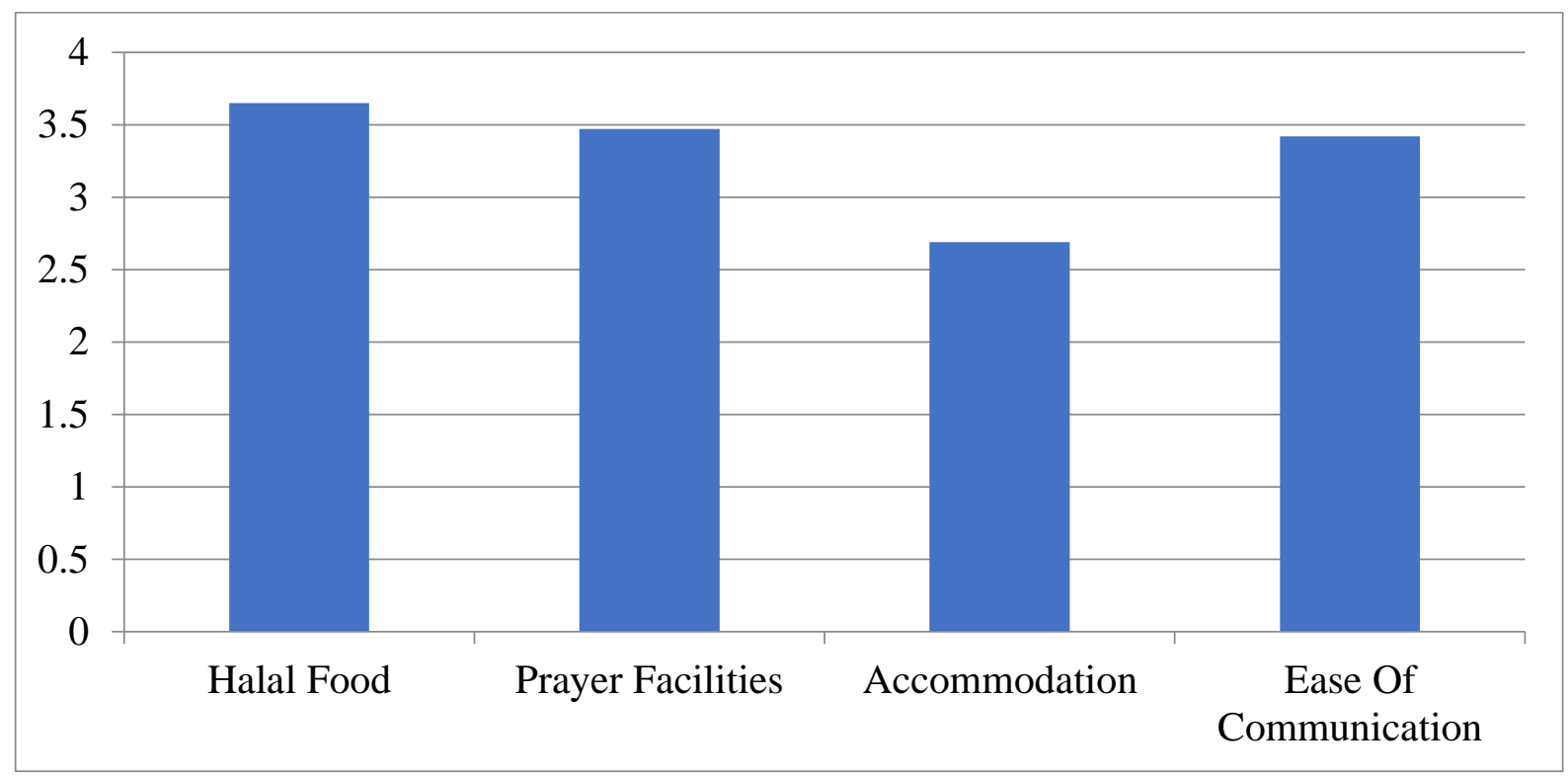

Figure 1: Descriptive analysis summary for all the components

\section{Section B: Halal Food}

The descriptive analysis of the responses provided by the participants regarding Halal food showed that the Muslim tourists are concerned about the Halal food they can access in japan. Statement B2 had the highest mean score of 4.53 , which shows that a large percentage of the participants agreed with it (see figure 2). This statement identifies the participant's understanding of what 'Halal' means implying that most of the respondents and, thus, tourists know how the concept applies in Islamic law. Therefore, a failure of the hotels and other food sources in Japan to adhere to Halal provisions diminishes the quality of experience that the tourists gain. Statement B1 received an equally sizeable mean score of 4.50, highlighting that most of the respondents are concerned with the status of Halal food before consumption (see table 3 ). This means that where the food has not been prepared using the proper religious guidelines will not be consumed. Both of these statements have standard deviations of 0.87 and 0.81 respectively showing that most of the responses are closer to the mean. This means that most respondents either agreed or strongly agreed with these statements. 
INTERNATIONAL JOURNAL OF ACADEMIC RESEARCH IN BUSINESS AND SOCIAL SCIENCES Vol. 10, No. 11, 2020, E-ISSN: 2222-6990 @ 2020 HRMARS

The statement B16 also received a score of 4.43, which shows strong support from the respondents. By concurring with it, the participants agree that food provides them with more pleasure as well as satisfaction while they travel. Therefore, it highlights the fact that most of the tourists enjoy eating during their tours, including Malaysian Muslim tourists. Moreover, it demonstrates the need for tourist restaurants and hotels in Japan should ensure that they observe Halal requirements if they are to improve the quality of their clients' experience. According to statement B4, which received a mean score of 4.42, 40.6 per cent of the respondents agree while 37.5 per cent strongly agree that they use directories to find Halal food premises in advance. Therefore, those food premises that do not meet Halal conditions seemingly do not get a lot of attention from the Malaysian Muslim visitors.

Statement B8 received the lowest mean score (2.95) in this section. The statement describes the visibility and availability of the Halal menu in the Japanese food premises. A large portion of the respondents was neutral $(33 / 7 \%)$ in their rating for this statement with only a small percentage on either side. This can be explained based on the fact that most of the Muslim tourists will not visit a restaurant before checking if it provides Halal food. For those who visit and yet still uphold Halal requirements, seeing the menu will influence their attitudes and perceptions of the place.

Table 3: Halal food descriptive analysis

\begin{tabular}{|c|c|c|c|c|c|c|c|c|}
\hline No. & Statement & SDA & DA & $\mathbf{N}$ & A & SA & Mean & SD \\
\hline B1 & $\begin{array}{l}\text { I am concerned about the } \\
\text { status of halal food before } \\
\text { eating. }\end{array}$ & $\begin{array}{l}8 \\
(2.8)\end{array}$ & $\begin{array}{l}2 \\
(0.7)\end{array}$ & $\begin{array}{l}4 \\
(1.4)\end{array}$ & $\begin{array}{l}97 \\
(33.7)\end{array}$ & $\begin{array}{l}177 \\
(61.5)\end{array}$ & 4.50 & 0.81 \\
\hline B2 & $\begin{array}{l}\text { I understand the concept } \\
\text { of halal food. }\end{array}$ & $\begin{array}{l}11 \\
(3.8)\end{array}$ & & $\begin{array}{l}6 \\
(2.1)\end{array}$ & $\begin{array}{l}78 \\
(27.1)\end{array}$ & $\begin{array}{l}193 \\
(67.0)\end{array}$ & 4.53 & 0.87 \\
\hline B3 & $\begin{array}{l}\text { I only choose food with } \\
\text { halal logo. }\end{array}$ & $\begin{array}{l}15 \\
(5.2)\end{array}$ & $\begin{array}{l}67 \\
(23.3)\end{array}$ & $\begin{array}{l}29 \\
(10.1)\end{array}$ & $\begin{array}{l}95 \\
(33.0)\end{array}$ & $\begin{array}{l}82 \\
(28.5)\end{array}$ & 3.56 & 1.26 \\
\hline B4 & $\begin{array}{l}\text { I refer to the directory of } \\
\text { halal food premises in } \\
\text { advance as a guide. }\end{array}$ & $\begin{array}{l}6 \\
(2.1)\end{array}$ & $\begin{array}{l}23 \\
(8.0)\end{array}$ & $\begin{array}{l}34 \\
(11.8)\end{array}$ & $\begin{array}{l}117 \\
(40.6)\end{array}$ & $\begin{array}{l}108 \\
(37.5)\end{array}$ & 4.03 & 1.00 \\
\hline B5 & $\begin{array}{l}\text { I feel confident with the } \\
\text { premises that have halal } \\
\text { logo. }\end{array}$ & $\begin{array}{l}9 \\
(3.1)\end{array}$ & $\begin{array}{l}2 \\
(0.7)\end{array}$ & $\begin{array}{l}16 \\
(5.6)\end{array}$ & $\begin{array}{l}94 \\
(32.6)\end{array}$ & $\begin{array}{l}167 \\
(58.0)\end{array}$ & 4.42 & 0.88 \\
\hline B6 & $\begin{array}{l}\text { I know the recognized } \\
\text { halal logo in Japan. }\end{array}$ & $\begin{array}{l}11 \\
(3.8)\end{array}$ & $\begin{array}{l}23 \\
(8.0)\end{array}$ & $\begin{array}{l}59 \\
(20.5)\end{array}$ & $\begin{array}{l}100 \\
(34.7)\end{array}$ & $\begin{array}{l}95 \\
(33.0)\end{array}$ & 3.85 & 1.09 \\
\hline B7 & $\begin{array}{l}\text { I only visited the premises } \\
\text { that display the halal logo. }\end{array}$ & $\begin{array}{l}21 \\
(7.3)\end{array}$ & $\begin{array}{l}67 \\
(23.3)\end{array}$ & $\begin{array}{l}48 \\
(16.7)\end{array}$ & $\begin{array}{l}86 \\
(29.9)\end{array}$ & $\begin{array}{l}66 \\
(22.9)\end{array}$ & 3.38 & 1.27 \\
\hline
\end{tabular}


INTERNATIONAL JOURNAL OF ACADEMIC RESEARCH IN BUSINESS AND SOCIAL SCIENCES Vol. 10, No. 11, 2020, E-ISSN: 2222-6990 @ 2020 HRMARS

The halal menu is clearly

$\begin{array}{llllllllll}\text { B8 } & \text { visible and } & \text { readily } & 35 & 64 & 97 & 65 & 27 & 2.95 & 1.15\end{array}$

Halal food premises are $\begin{array}{llllllllll}\text { B9 easily found at the } & \begin{array}{l}14 \\ \text { Birport. }\end{array} & 66 & 82 & 85 & 41 & 3.25 & 1.11 \\ & & & (4.9) & (22.9) & (28.5) & (29.5) & (14.2) & & \end{array}$

Halal food premises are

B10

easily found in tourist

locations.

$\begin{array}{lllll}17 & 61 & 98 & 79 & 33\end{array}$

$(5.9) \quad(21.2) \quad(34.0) \quad(27.4) \quad(11.5)$

$3.17 \quad 1.07$

Halal food is readily

$\begin{array}{lllllllll}\text { B11 } & \text { available in higher } & 17 & 52 & 153 & 45 & 21 & 3.00 & 0.93\end{array}$

There is a variety of halal

$\begin{array}{lllllllll}\text { B12 menus in halal premises. } & 15 & 59 & 98 & 84 & 32 & 3.20 & 1.05\end{array}$

I feel confident with the

\begin{tabular}{lllllllll}
\multirow{2}{*}{ B13 food I eat even though } & 47 & 56 & 44 & 95 & 46 & 3.13 & 1.34 \\
& there is no halal logo. & $(16.3)$ & $(19.4)$ & $(15.3)$ & $(33.0)$ & $(16.0)$ & &
\end{tabular}

I am confident to eat halal

food at the same

$\begin{array}{lllllllll}\text { B14 } & \begin{array}{l}\text { premises serves non-halal } \\ \text { food. }\end{array} & 36 & 46 & 88 & 78 & 40 & 3.14 & 1.21\end{array}$

I feel confident with the

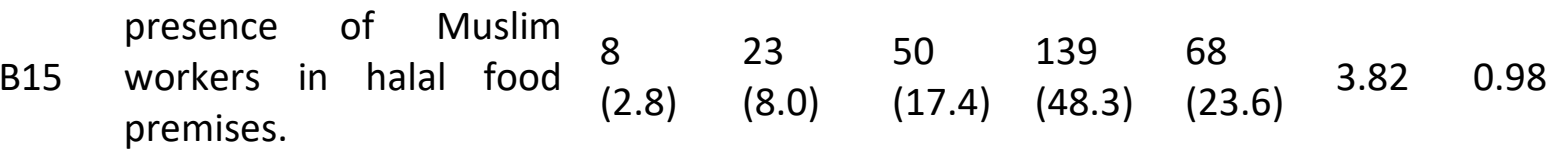

The convenience of

B16 motting halal food gives satisfaction when

$\begin{array}{lllllll}8 & 8 & 13 & 83 & 176 & & \\ (2.8) & (2.8) & (4.5) & (28.8) & (61.1) & 4.43 & 0.92\end{array}$
travelling. 
INTERNATIONAL JOURNAL OF ACADEMIC RESEARCH IN BUSINESS AND SOCIAL SCIENCES Vol. 10, No. 11, 2020, E-ISSN: 2222-6990 @ 2020 HRMARS

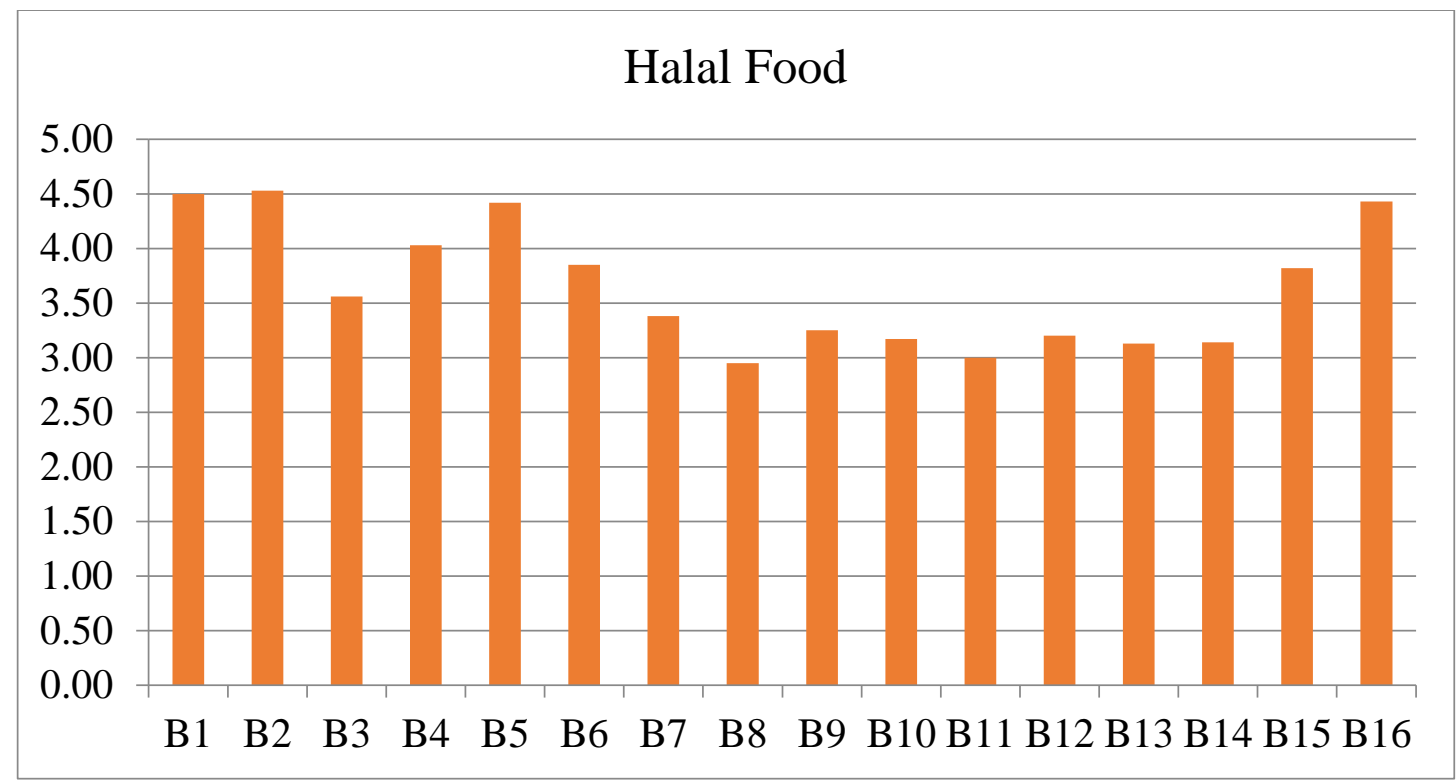

Figure 2: Halal food descriptive analysis

\section{Section C: Level of Satisfaction}

This section of the report will focus on summarising the satisfaction levels of the respondents with regards to Halal food and prayer facilities. The responses were categorized into three groups, namely: low (1-2.33), moderate (2.34-3.67) and high (3.68-5.00). In the tables, the frequency demonstrates the number of participants that selected the option (level of satisfaction) while the percentage shows the portion of the participants that chose each level.

Table 4: The level of satisfaction in Halal food

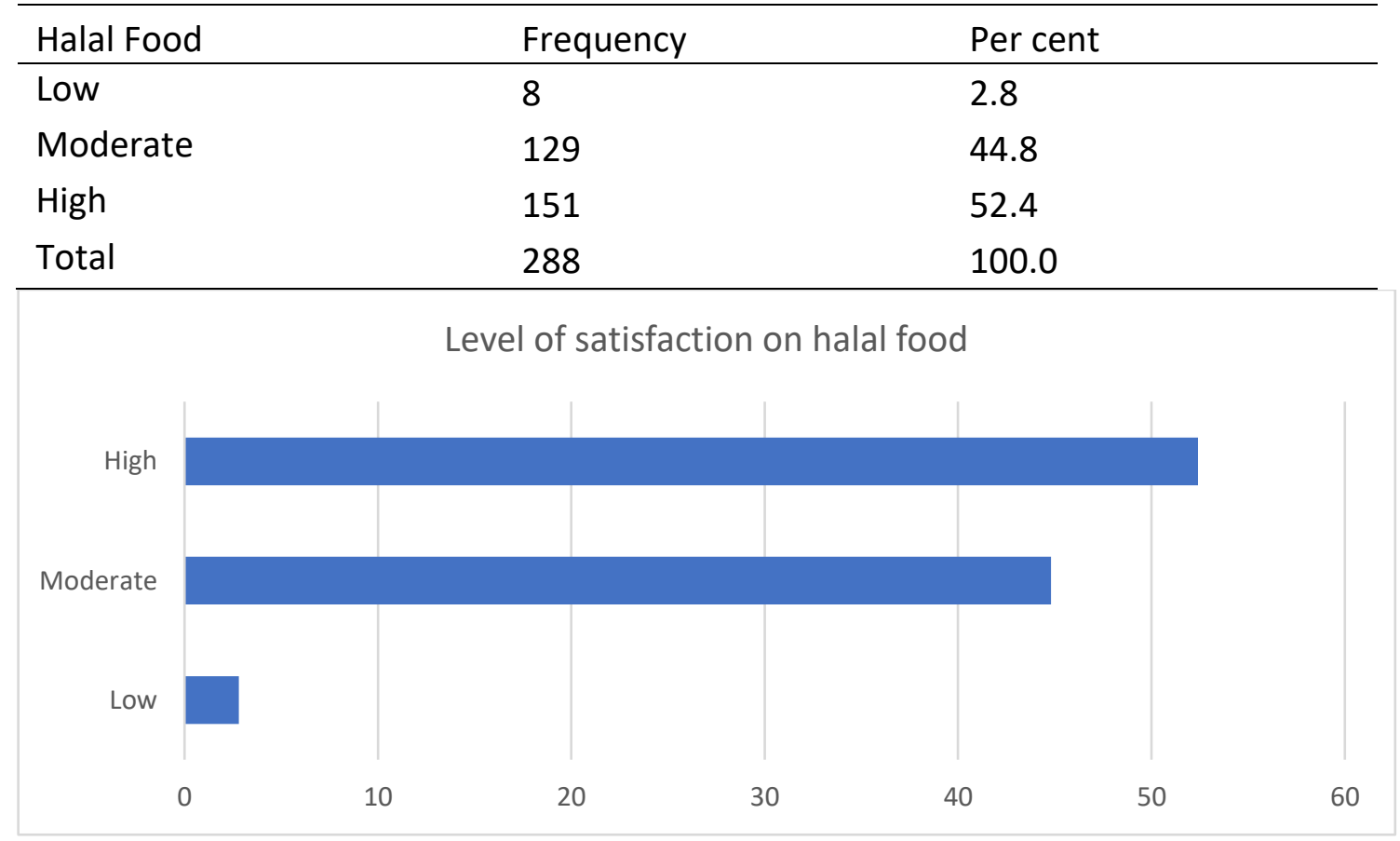

Figure 3: The level of satisfaction in Halal food 
INTERNATIONAL JOURNAL OF ACADEMIC RESEARCH IN BUSINESS AND SOCIAL SCIENCES Vol. 10, No. 11, 2020, E-ISSN: 2222-6990 @ 2020 HRMARS

\section{Conclusion}

Based on the analysis of survey data, the level of satisfaction on Halal food was high, considering that more than half of the participants were in consensus (52.4\%). A further $44.8 \%$ were moderately satisfied with the Halal foods in the Japanese hospitality industry as opposed to the $8 \%$ who were dissatisfied (See table 4). These results indicate a significant degree of quality as far as Halal foods are concerned. According to Teshnizi et al. (2018), service quality is the assessment of the extent to which a particular service conforms to the customer's expectations. In the context of these descriptive results, it appears that the organizations in question strive to meet the client's expectations as far as serving Halal food is concerned. This calls for strict adherence to the Islamic religious culture since the term 'Halal' denotes acceptability, it is essential to provide them with food prepared desirably. For example, slaughtering animals follows a particular process, including draining the blood entirely from the carcass. Hotels and restaurants should avoid pork as well as slaughtering sickly and poorly fed animals since they violate core Islamic beliefs.

Additionally, the selection of suitable modern and trendy methods to prepare food should be approached carefully. It is necessary to ensure that the equipment is in order with Islamic principles. This is because the Quran speaks on edicts and rules pertinent to maintaining animal welfare and individuals have to follow to gain the Lord's favour. For instance, animals are not slaughtered in one place because one must not see the other die. Demonstrating to Muslim customers this support for their tenets is responsible for gaining trust necessary to operate in Islamic-based communities. Hence, this study has recommended the following suggestions:

1- Providing more halal menus, including local and traditional food, especially in central tourist locations.

2- Encouraging halal food operators to obtain halal certificates and exhibit halal logos on-premises to boost Muslim tourists confidence and convenience of choosing food and services provided. A logo is a form of communication that delivers information to customers, and it can substitute verbal explanations that may not be able to communicate by employees or premises managers who do not understand the halal concept.

3- Providing food ingredient information in a widely used language such as English.

4- Providing information required by Muslim tourists such as halal food, prayer time and Qibla direction at the hotel counters and tourist information centres.

The findings of this study are an essential effort to identify the viewpoint of Muslim tourists towards halal food and their satisfaction with halal services and hospitality in Japan. As initially stated, Japan is aggressively promoting halal tourism in recent years and is gaining ground compared to other Asian countries in providing a halal-friendly environment for Muslim tourists worldwide. Therefore, this study helps Japan's halal tourism identify how Muslim tourists feel while traveling in Japan. Moreover, this study provides recommendations on overcoming the identified factors that result in dissatisfaction among travelers. And importantly, the findings of this study will be a helpful hand for players in the halal industry in Japan to improve their services and facilities and to shift their approach in hospitality areas of Halal tourism. 
INTERNATIONAL JOURNAL OF ACADEMIC RESEARCH IN BUSINESS AND SOCIAL SCIENCES

Vol. 10, No. 11, 2020, E-ISSN: 2222-6990 @ 2020 HRMARS

\section{Acknowledgement}

This work was supported by The Sumitomo Foundation, Fiscal 2015 Grant For Japan-Related Research Projects.

\section{References}

Agriculture and Agri-Food Canada (2011). Global Halal food market. Available at http://www.ats.agr.gc.ca/inter/4352-eng.pdf. Retrieved on October 22, 2020.

Benner, T. (2015). Halal products draw more Muslim tourists to Japan. Retrieved from http://www.japantoday.com/category/lifestyle/view/

Brian J.G. et al. (2011). The future of the global Muslim population: projections for 20102030.Washington D.C. PEW Research Center.

Consumers Association of Penang. (2006) Halal and Haram: An important Book for Muslim Consumers. Pulau Pinang Malaysia: CAP

CrescentRating. (2018). Global Muslim Travel Index 2018 (GMTI 2018). Singapore: Mastercard Asia Pacific Pte. Ltd.

CrescentRating. (2015). Japan Welcomes halal tourism. Retrieved from http://www.crescentrating.com/blog/item/3658-japan-welcomes-halal-tourism.html on October 22, 2020

Eid, R., \& El-Gohary, H. (2015). The role of Islamic religiosity on the relationship between perceived value and tourist satisfaction. Tourism Management, 46, 477-488

El-Maghrabi, N. M., Soliman, M. A., \& Adli, M. A. (1995). Islam in Japan: The History of Islam in Japan. Retrieved from http://www.islamawareness.net/Asia/Japan/history.html, dated October 22, 2020.

Evan, S. (2017). Opinion: Why are so many Muslims suddenly visiting Japan? Retrieved from https://halalfocus.net/opinion-why-are-so-many-muslims-suddenly-visiting-japan/ dated October 22, 2020

Henderson, J. C. (2016). Halal food, certification and halal tourism: Insights from Malaysia and Singapore. Tourism Management Perspectives, 19, 160-164.

Japan Halal Association. (2012). JAKIM recognized certification body in Japan. Retrieved from http://www.jhalal.com/english. Retrieved 23 May, 2012.

Kojima H. (2006). Variations in demographic characteristics of foreign Muslim population in Japan: a preliminary estimation. The Japanese Journal of Population. 4(1); 115-130.

McDaniel, S. W., \& Burnett, J. J. (1990). Consumer religiosity and retail store evaluative criteria. Journal of the Academy of Marketing Science, 18, 101-112.

Mohsin, A., Ramli, N., \& Alkhulayfi, B. A. (2016). Halal tourism: Emerging opportunities. Tourism Management Perspectives, 19, 137-143. https://doi.org/10.1016/j.tmp.2015.12.010

Shakona, M., Backman, K., Backman, S., Norman, W., Luo, Y., \& Duffy, L. (2015). Understanding the traveling behavior of Muslims in the United States. International Journal of Culture, Tourism and Hospitality Research, 9(1), 22-35.

Tan, C. K. (2015). The rise of halal tourism. Retrieved from http://asia.nikkei.com/magazine/20150326-Singapore-after-Lee/Business/ on October 22, 2020

Weidenfeld, A., \& Ron, A. S. (2008). Religious Needs in the Tourism Industry. Anatolia, 19(2), 357-361 